\title{
Suggestive Therapeutics: New Thought's Relationship to Modern Yoga
}

\author{
Mark Singleton
}

\begin{abstract}
Modern, transnational yoga in the early twentieth century often defined itself in terms and ideologies borrowed from the popular current of esoteric American Protestantism known as New Thought. Like its forebear Transcendentalism, the New Thought movement was itself receptive to Indian ideas, albeit radically reworked to fit the doctrine of divinised self-hood and cosmic healing that it purveyed. Such adaptations were dialectically reabsorbed by exponents of the yoga renaissance, in a mutually reinforcing, cross-cultural rewriting of the theoretical bases and practices of yoga. New Thought provided a convenient and familiar spiritual lexicon with which to convey the arcane truths of yoga to Europeans, Americans and (increasingly) modern Hindus. The result was a new understanding of yoga in terms of the cult of positive thinking, personal power and affluence, and health through perfect harmony with the universe.
\end{abstract}

\section{Keywords}

modern yoga, New Thought, psychosomatic therapy, physical culture, metaphysical religion

\section{Introduction}

It took Coué to teach us the virtue of Japa, or constant meditation upon a certain idea, or Haddock to instruct us in the importance of will-power, or William James to enlighten us on the significance of mental control. Any one who reads the works of these men even cursorily and compares their teachings with those of ancient Indian sages will not fail to be struck with wonder at the resemblance. ${ }^{1}$

In the early days of its accession to the catalogue of western esoteric technology, popular practical yoga was consistently confounded with the heterogeneous array of beliefs and praxis that went variously under the names of 'Mind Cure', 'New Thought' and, more colloquially, 'The Boston Craze'. Originally a break-away faction of Mary Eddy Baker's Christian Science, New Thought

\footnotetext{
' Pratinidhi 1938, p. 105. Pratinidhi, the Rajah of Aundh, was the creator of the süryanamaskära system of modern postural yoga.
} 
began in New England in the 1880s as a broad-based, para-Protestant movement preaching the innate divinity of the self and the power of positive thinking to actuate that divinity in the world, usually to the ends of personal affluence and health. It is no exaggeration to say that elements of these popular esoteric doctrines are so standardly present in practical yoga primers intended for the European and American reading public that it is unusual not to find some degree of blending during the first half of the twentieth century. It seems to have been widely taken for granted that positive thinking, auto-suggestion and the 'harmonial', this-worldly belief framework of New Thought was not so much a contribution to yoga as its expression (albeit in optimistic, Americanised accents). Conversely, it was largely assumed that yoga was the perennial, exotic repository of these newly (re-)discovered truths. Modern yoga would not be what it is today without New Thought, which represented a popular revolution in personal religious belief. Although it was born in America, the eclectic doctrines quickly spread beyond these borders to Europe and India, where they were adapted to local temperaments and tastes. Although it had lost much of its demotic punch by the end of the Second World War, New Thought ideas have endured in one form or another up to the present, and many assumptions about what it means to practise yoga in the West today can be traced back to them. If modern yoga is an emulsion of many shades and elements, New Thought gave it its sunniest hue.

In this article, I will examine how this merger with New Thought came about, and to what extent it has altered the meaning of yoga itself, both in India and the West. I begin with an examination of the salient features of New Thought, before considering how certain adherents of this philosophy tactically used elements of 'Indian' thought to lend authority to their own movement. In this model, certain core beliefs about the individual's ontological make-up and function in the universe are pragmatically modified to cohere with this prevalent world view. I then focus more specifically on the influence of Emile Coué, whose method of auto-suggestion and affirmation became so central to both New Thought and modern expressions of yoga. In fact, Coués work was commonly regarded as a reliable technical resource for the prospective practitioner of 'yoga', and his system of affirmations respected as a local expression of Indian mantras. I then consider the role of the body in New Thought, and the extent to which it displaced classical hatha conceptions of physicality in the new yoga. Examining the early American work of Paramahamsa Yogananda, I suggest that the 'muscle control' emphases of modern yoga derive in large part from New Thought-influenced bodybuilding in the traditions of Jules Payot and Frank Channing Haddock. Finally, I briefly turn to the enigmnatic Yogi Ramacharaka, a phantom Indian adept who emanated from the 
imagination of a well-known New Thought writer early in the twentieth century. Ramacharaka represents perhaps the exemplary convergence of New Thought and yoga: through a brief reading of his 1904 book Hatha Yoga, I consider how certain questionable assumptions about what it means to practise yoga came to be established as fact in the popular mind. ${ }^{2}$

\section{New Thought}

The fundamental concern of New Thought, as its alternative moniker 'mind cure' suggests, is with health and healing-whether it be of the body, the psyche or the bank balance. A tremendously popular vehicle of the diffuse impulse of unchurched Protestant religiosity that Sidney Ahlstrom terms 'harmonial religion', ${ }^{3} \mathrm{New}$ Thought did much to revolutionise the religious life of urban America and, to a lesser extent, Britain. As Fuller summarises, in harmonial religion, 'spiritual composure, physical health, and even economic well-being are understood to flow from a person's rapport with the cosmos', ${ }^{4}$ and it was the special contribution of New Thought to render this metaphysical conviction into practical technique. One of the founding figures of New Thought was Phineas P. Quimby, who put forward the startling hypothesis that patients under hypnosis recovered from disease simply as a result of their own beliefs, rather than from any special talent of the therapist. By the same reasoning, disease was seen as being caused by fundamentally wrong beliefs. Quimby's speculative aetiology was disseminated and popularised by his influential disciples, most notably Mary Baker Eddy (the founder of Christian Science), Warren Felt Evans and Anetta and Julius Dresser. ${ }^{5}$ Through them and others, the cult of positive thinking that came to be known as New Thought gained widespread acceptance.

An authoritative twentieth-century spokesman of New Thought, Horatio W. Dresser (son of Anetta and Julius), gives the following summary of the movement's credo:

The New Thought stands for the affirmative attitude. It affirms success even amidst failure. It endeavors to compass the whole of life, and to show that there

${ }^{2}$ Catherine Albanese's just-published cultural history of American metaphysical religion, $A$ Republic of Mind and Spirit (2007) addresses some of the same issues that I raise in this article. While I did not have time to fully take into account Albanese's discussion, I nevertheless refer the reader to this broad-ranging, impressive new work, and in particular chapter 6 .

${ }^{3}$ Ahlstrom 1972.

${ }^{4}$ Fuller 2001, p. 51.

5 See Meyer 1965 and Parker 1973 for the early history of Mind Cure and New Thought. 
are inner resources for every possible need or occasion [...] It is a vigorous gospel of health and healing. It is constructive, positive, optimistic; believes in the supremacy of the good, the triumph of ideals, the development of productive individuality. ${ }^{6}$

The relentlessly upbeat, individualistic philosophy so familiar today through a panoply of self-help books was originally propagated largely thanks to apostles, like Dresser, of what William James called 'The Religion of HealthyMindedness.' Indeed, the naturalisation of radical optimism that began during the final decades of the nineteenth century very quickly displaced, in certain circles, more traditional, orthodox beliefs about the individual's place in the universe. William Walker Atkinson, a prolific New Thoughter and (as we shall see) enthusiastic proselyte of yoga, chronicles this pervasive new zeitgeist, which he terms 'The Spirit of Optimism', in his The Message of New Thought of 1911:

People who never heard of the New Thought found themselves impressed with the importance of Being Cheerful, Looking on the Bright Side, and Keeping Sweet. 'Don't Worry' signs and motto-cards were noticed on all sides. And, also, a new spirit of Self-Reliance and Self-Help was manifested.'

All this, he declares, has come about in the previous 25 years due to the influence of New Thought. Health, wealth and happiness, in his view, have ceased to be the privilege of the few, and have become the birthright of all. ${ }^{10}$ However, it is worth noting that New Thought was largely an urban revolution among white, Anglo-Saxon, upper middle-class Protestants (mainly women) seeking relief from the psychosomatic blights of city living. ${ }^{11}$ It was the same demographic cross-section, indeed, which embraced neo-yoga, probably for similar reasons. ${ }^{12}$

New Thought was a diffuse and decentralised movement with no standard set of tenets or rules. As Atkinson rightly affirms, it was 'merely a body of affiliated thinkers' lacking in organisational cohesion. ${ }^{13}$ Indeed, much of its appeal probably lay in this loose, nebulous structuration which, Marie Griffith notes, 'encouraged its adoption by a wide range of Americans, from orthodox

${ }^{6}$ Dresser 1917, p. iii.

7 James 1971. This was also thanks to the advocacy of James himself.

${ }^{8}$ Note that Horatio Dresser criticises this book for misrepresenting New Thought (Dresser n.d., p. 312).

'Atkinson 1911, p. 20.

${ }^{10}$ Atkinson 1911, p. 27.

"Fuller 2001, p. 186 n.10.

12 See Singleton 2005.

${ }^{13}$ Atkinson 1911, p. 34. 
believers to settled nonbelievers. ${ }^{14}$ However, a core belief around which the manifold heterodox practices proliferated was, as Dresser puts it in his Handbook of New Thought, 'God in us' as opposed to the more traditional view of 'God with us', or 'God outside the world'. ${ }^{15}$ In this bright new world, suffering, sacrifice and guilt are eradicated as the divinised individual manufactures her own ontological analgesia from the inexhaustible font of happiness that is the True Self. As 'the therapeutic practice of the presence of God', ${ }^{16}$ indeed, New Thought expresses a more general shift within American and British religious sensibilities from a communal religiosity based on the supplication of an (external) deity, to a privatised liturgy of self-healing and purification. ${ }^{17}$ As a form of spirituality assumed to epitomise these sacred aspirations, yoga was often held up as the ideal for western religious seekers. This paragon of spiritual practice systems was, however, itself in a constant state of dialectical adaptation to the range of beliefs of which it was intended to be the blueprint. That is to say, yoga itself mutated through its dialogue with New Thought.

\section{New Old Thought}

New Thought is constantly characterised by its adherents as a revival of ancient perennial esoteric wisdom, and in particular Indian wisdom. Speaking at the 1993 Parliament of the World's Religions, which marked the centenary of Modern Yoga's arrival in the West via Vivekananda, contemporary New Thought apologist Alan Anderson defined the New Thought movement as 'a link between East and West', insisting that it 'is well-suited as a bridge to assist the traveler in passing easily from one realm of thought to the other [...] Both gain additional territory to explore without loss off their original holdings'. ${ }^{18}$ The New Thoughter can, in other words, stroll abroad in the garden of Indian thought and pick what she finds most fragrant. Similarly, the Indian philosopher is at liberty to avail himself of the conveniently updated methods of New Thought. The result: a fuller spiritual fruit basket for all. In this sense, New Thought and modern yoga should be considered as eclectic as opposed to syncretic movements in so far as they both represent 'a particular method of change-a method based on conscious selection'-rather than a (syncretic)

${ }^{14}$ Griffith 2001, p. 122.

15 Dresser 1917, p. vi.

${ }_{16}$ Dresser 1917, p. 16.

17 Jackson 1975, p. 526. See Pinch 2003 for a consideration of such trends in Victorian England and their formative influence on devotional religious practice (bhakti) in India

${ }^{18}$ Anderson 1993, p. 1. 
'broad process of historical change and systemic interaction among religions'. ${ }^{19}$ That New Thought consciously selects the elements that it takes from Indian philosophy is clear in Anderson's endorsement of 'the Hindu [i.e. Advaita Vedantin] view that ultimate reality and the world, including oneself, are one', and his concomitant rejection of Advaita's incompatible belief in māya. ${ }^{20}$ Preserving the western view 'of a real (if mental) universe with real, permanent human beings' allows the worldly New Thoughter to elide the more awkward aspects of Indian soteriology-in particular, the bitter fruit of duhkha (suffering) and the quest for liberation at the heart of the orthodox darsanas which it entails. Anderson euphemistically recognises that there has always been in New Thought 'some tension between these two emphases', but does not admit of any incommensurability. ${ }^{21}$

Indeed, New Thought has had a long and ambivalent relationship with Indian religion, from which it draws a peculiarly selective inspiration. Horatio Dresser employed a common strategy of selective assimilation when he defined New Thought in 1917 as 'the rediscovery in our time of principles known long ago in ancient India', but simultaneously rejected the more undesirable elements of 'the Vedanta philosophy'. ${ }^{22}$ It would be well, he explained, 'to push Occidental individualism through to the end to see if it offers a more satisfactory explanation'. ${ }^{23}$ As some New Thoughters such as Dresser were aware from the start, Yankee optimism sits uneasily with a universe whose defining characteristic (as far as human beings are concerned) is suffering and pain. Carl Jackson has pointed out that when 'Indian' notions like reincarnation and karma are taken up in New Thought literature, they are generally modified to transmit a characteristically American message of hope. Thus reincarnation is no longer baleful subjugation to the wheel of death and rebirth, but an optimistic promise of a renewed, and better, life. ${ }^{24}$ Although Dresser represents a more acute philosophical and critical sensibility than the majority of New Thought writers, the tension between certain Indian liberation theologies and mind cure optimism is nonetheless pervasive, if often tacit.

${ }^{19}$ Hatcher 1999 , p. 8.

${ }^{20}$ Anderson 1993, p. 2. Consider also the assertion of Yogi Ramacharaka (of whom more later) that ' $[w]$ e belong to what is known as the ECLECTIC SCHOOL of Hindu Philosophy [...] "Eclectic", you know, means Selective; Chosen from various sources and systems' (Ramacharaka 1908, p. 8).

${ }^{21}$ Anderson 1993, p. 2.

22 Dresser 1917, pp. 25 and 71.

${ }^{23}$ Dresser 1917, p. 71.

${ }^{24}$ Jackson 1975, pp. 531-2. See also Bharati 1976, p. 157: 'Now millions of India-inspired occidentals probably believe in rebirth, but they like it.' 
New Thought's championing of Indian thought, and yoga in particular, is part of the larger fin-de-siècle Oriental vogue which swept Swami Vivekananda to prominence after his American debut at the Parliament of Religions in 1893. As Arthur Versluis and Catherine Albanese have both pointed out, Transcendentalists like Emerson and Thoreau had prepared the ground for the entry of Hindu concepts into the American consciousness, and New Thought seized on this extensive work and made it accessible in popular, piecemeal form. ${ }^{25}$ When Vivekananda arrived in America, he found a New Thought audience already imbued with notions of Indian spirituality, and receptive to his rendering of what Elizabeth De Michelis has argued was essentially a western esoteric version of yoga. ${ }^{26}$ Indeed, Vivekananda, along with his co-workers Saradananda and Abhedananda, 'made a profound impression upon members of the New Thought movement' and 'appeared frequently before New Thought audiences'. ${ }^{27}$ Their message, radically adapted for their public, did not seriously challenge the prevalent, harmonial beliefs of turn-of-the-century America, but did serve to feed the popular myth that New Thought was a modern recrudescence of an ancient tradition.

\section{Modern yoga}

It is significant, if not very surprising, that many authors of early practical yoga manuals_-such as R. Dimsdale Stocker, O. Hashnu Hara, Charles Wase, S. D. Ramayandas and Yogi Ramacharaka-also wrote books devoted to New Thought themes; that New Thought titles rubbed shoulders with yoga primers in the catalogues of esoteric publishers like L. N. Fowler in London and Fowler and Wells in New York; and that yoga manuals were filled with advertisements for New Thought self-help books. Both topics, it would seem, had the same target audience. For example, S. D. Ramayandas's First Steps in Yoga (published by L. N. Fowler in 1926) was distributed with an inserted advertisement slip promoting the books of New Thought luminary Henry Harrison Brown, including Success: And How Won through Affirmation, How to Control Fate Through Suggestion, and the intriguing Dollars Want Me. Given the proximity of theme, content and marketing strategy, one must assume that not much critical distinction was drawn between yoga and New Thought in the mind of the average reader. And indeed, how could it be when the only mate-

\footnotetext{
${ }^{25}$ Versluis 1992; Albanese 1993.

${ }^{26}$ De Michelis 2004.

27 Jackson 1975, p. 529.
} 
rial on yoga that was readily and cheaply available was itself shot through with the messages of New Thought? New Thought approached the Hindu tradition like a donor body, expropriating individual organs according to their use value in the new corpus, rather than as integral elements of the old.

The American movement tended to laud the independent, self-willed and divinised self, in contrast to the perceived mystical selflessness of India. Rather than let sleeping gods lie, however, New Thought-inspired authors took it upon themselves to revise 'Indian thought' along these voluntaristic western lines and in the process-through a kind of thematic and linguistic overkillto permanently alter the meaning of yoga in the popular imagination. Consider the following statement by Horatio Dresser:

As the New Thought works its way into the far East, it will be on a practical basis, by supplying a method of realization and healing, and an activity or affirmationism usually lacking in countries where mysticism prevails. ${ }^{28}$

In Dresser's view, the Indian model is sadly lacking in practical applicability, and it is the job of New Thought, as it comes into contact with these erring philosophies, to contribute the pragmatic correctives of therapy, positive thinking and affirmation. To a large extent, this is precisely what seems to have happened in the field of popular transnational yoga, as the epigraph to this article from the Rajah of Aund suggests. ${ }^{29}$ The obvious but paradoxical rationale for this vision of benevolent evangelism (rehearsed over and over by popular yoga authors) is that New Thought is 'the oldest philosophical system of the race ${ }^{30}$ and that, by adapting and rectifying the Vedanta, modern authors are merely restituting the ur-philosophy of humankind. Thus, R. Dimsdale Stocker's 1906 Yoga Methods, How to Prosper in Mind, Body and Estate (the garish title perhaps reflects more the astute marketing strategy of the publishers than the book's reasonably down-to-earth contents) claims New Thought as 'the oldest form of thought of which we have any record extant '. ${ }^{31}$ The 'yoga' in this and other books is presented less as an adaptation of Indian techniques than their restoration in original, uncorrupted form. With the rise to prominence of these and similar assumptions, statements concerning the purpose of

${ }^{28}$ Dresser n.d., p. 274.

${ }^{29}$ Consider also Wase 1921, which announces itself as 'an attempt to make the deeper philosophy of the East available in practical right-thinking in daily life and action in the Western world' (v). While yoga in India is largely contemplative, opines Wase, 'the people of the Western world must remember' that it can also bring them 'Mental Power and the capacity to dominate environment' (viii). While New Thought and yoga 'do not really clash' (p. ix), the latter should principally be used as a corrective adjunct to the former.

${ }^{30}$ Atkinson 1911, p. 2.

${ }^{31}$ Stocker 1906, p. 8. 
yoga begin to reveal less about Indian traditions of the past and more about the development of New Thought itself. Such claims clearly comprise a double rhetorical function: on the one hand, they domesticate and familiarise the alien tradition of yoga to an American audience, and on the other they lend New Thought practices the venerable authenticity of an ancient wisdom tradition.

Arthur Versluis has argued that the eclecticism of New Thought resulted in the presentation of Asian religion 'in popularized and distorted form'. The convictions and beliefs of those who engaged in New Thought practices, he avers,

had only the most tenuous connections to Asian religions, having much more to do with how people in a rapidly industrializing society could find quasi-religious solace in a Darwinian world that denied Christianity except in the most denatured forms. ${ }^{32}$

While I would be cautious about judging modern forms of yoga as 'distortions', it is clear that neo-yogas (i.e. any of the various popular, transnational syntheses at large in the West today) often poignantly manifest such rewritings of Asian religion. Often, too, they can epitomise the 'anthropotheism' which Versluis singles out in New Thought, and the movement's overarching rationale concerning the core commensurability of all religions. Such a model, Versluis contends, 'always exists at the expense of particularities, as when a fable is condensed into a single aphorism'. ${ }^{33}$ I would argue that from its beginnings in the late nineteenth century, popular modern yoga has tended to function like a free market economy, in which spiritual goods are exchanged and synthesised, and in which the 'trade barriers' of insular, secretive traditions are lifted. ${ }^{34}$ New Thought was instrumental in furthering this process of spiritual 'deregulation'.

\section{Coué and affirmation}

When O. Hashnu Hara, in his Practical Yoga, with a chapter devoted to Persian Magic (1906), suggests that 'New Thought and Suggestion' are techniques which have been borrowed from yoga, he is voicing a widely held and little

32 Versluis 1993, p. 314.

${ }^{33}$ Versluis 1993, p. 191.

34 Vivekananda once explained to his anglo-Irish disciple Sister Nivedita (a.k.a. Margaret Elizabeth Noble, 1867-1911) 'that he was in the West, because he believed that the time had come when nations were to exchange their ideals, as they were already exchanging the commodities of the market' (Nivedita 1967, p. 18). 
challenged belief that mesmeric auto-suggestion hails from the cradle of Hinduism. ${ }^{35}$ The assimilation of practical affirmations into the canon of popular modern yoga methods was so thorough, indeed, that there is rarely any critical distinction made between the economic and spiritual affluence idealised by New Thought, and the supposed summum bonum of yoga. For instance, in B. Patra's curious melange of parlour esoterica and yoga of 1924, hatha yoga pränäyama techniques are combined with auto-suggestion and visualisation to materialise worldly gain: '[v]isualise what you want', the reader is told, 'and if you do it long enough you will get'. ${ }^{36}$ In a similar vein, Stocker praises the benefits of self-sufficiency, and laments those who fail in their worldly endeavours because they have not 'apprehend[ed] our possibilities and powers and affinities' through the affirmative practices of yoga. ${ }^{37}$ The name most commonly associated with techniques of suggestion and affirmation during this period is that of Emile Coué (1857-1926), a French psychologist and pharmacist whose doctrine of positive thought and mental healing enjoyed an unparalleled vogue in Europe and America in the first decades of the twentieth century. His two books My Method (1923) and Conscious Auto-Suggestion (1924), which appeared relatively late in his career, did much to spread his message abroad, where it was eagerly embraced by positive thinkers and yoga enthusiasts alike. Vasant Rele, in his extremely influential scientific study of physiological yoga phenomena, The Mysterious Kundalini (1927), is representative of the tendency-already deeply ingrained by the time he wrote his book-to view Couéism as simply a modernised version of yoga. Writing of the interdependent 'limbs' of yoga, äsana, pränäyäma and dhäraṇä, Rele declares,

This is what the 'New Thought' literature, which is flooding the market, is trying to teach and this is what Emile Coué of France tells us to do to keep diseases away by concentrating our thoughts on his favourite formula: 'Day by day, in every way, I am getting better and better.' These thoughts may be new to the western world but to us they are as old as the hills. ${ }^{38}$

From this passage, dhäranä, and the yogic enterprise as a whole, can be read as a kind of pep talk to the subconscious. The general shift effected by popular modern yogas towards the paradigm of the therapeutic tool is, I would argue, partially a result of the pervasiveness of Coués method on the collective esoteric psyche. Once it became accepted that Couéism was yoga for the modern world, it was rare to find this view countered in popular yoga manuals (I have

\footnotetext{
35 Hara 1906 , p. 63.

36 Patra 1924, p. 143.

37 Stocker 1906, p. 41

38 Rele 1927, p. 9.
} 
found no such instance). Far more common are assertions such as the following by Hamish McLaurin in his explicitly occidentalised version of yoga theory and practice, Eastern Philosophy for Western Minds: '[w]hen Dr Coué popularized his system of autosuggestion through repetition of a word formula', he writes, 'he was re-stating nothing more than a well-recognized form of mental and physical therapeutics which has been practiced in India for countless generations ${ }^{39}$ But as we have seen, Coué was in practice as much 'for' anglicised Indian modern yoga gurus and pamphleteers as he was 'for' western minds, and although his name is virtually unknown in Englishspeaking yoga milieus today, his legacy remains pervasive.

That Coués techniques came to be widely accepted as authentic and central practices of yoga is also suggested by Geraldine Coster's 1934 comparison of yoga and psychology, which relates how,

a considerable number of western students who have been interested in yoga and have seriously used this [i.e. Coués] method as a means of altering habits and character have been cramped and stultified rather than aided by the practice. ${ }^{40}$

The moral of Coster's cautionary tale is not, however, that one should avoid Couéisms when one practises yoga, but merely that one should take care to pick the right affirmation. It is a clear indication that autosuggestion and yoga had by the 1930s become well melded in practice and theory, and that yoga was generally perceived to hold a principally (psycho-)therapeutic potential, through the reformation of the moral character of the individual. This is borne out in many practical manuals of the time, such as those by Ramayandas, where the yoga aspirant is encouraged to weed out character faults through affirmation. The author remarks that, " $[\mathrm{t}]$ here is no limit to the development of character by this method'. ${ }^{41}$ In the Coué model of yoga, the final ideals are moral reform and personal development (to the explicit end of efficacious agency in the (western) world) and not the life of quiet contemplation or absorption as an end in itself. ${ }^{42}$

\section{Mantra and affirmation}

As we have seen, Horatio Dresser's programme of a New Thought-infused Eastern spirituality becomes a reality in the project of early popular yoga in the

\footnotetext{
39 McLaurin 1933, p. 50.

${ }^{40}$ Coster 1934, p. 212.

${ }^{41}$ Ramayandas 1926, p. 20.

${ }_{42}$ Nor, for that matter, the onto-perceptual dislocation and 'cessation' which (arguably) lie at the heart of the 'classical' yoga of Patañjali (Grinshpon 2002; Sarbacker 2005).
} 
West, where it is embraced by Indians and westerners alike. Typically, a technique from the yoga tradition is taken, often in little more than name, and reinvested with a significance that is wholly absent from the original context. Once it is overlaid with these new associations, the original meaning is drastically obscured. One particularly clear example of this process is mantra which, under the influence of New Thought and Coué, loses its status as the 'mystical sound' of ritual observance and meditation, ${ }^{43}$ to become a knot in one's behavioural handkerchief. Of course, the reshaping of ritual into practical tools for transformation is typical of the pragmatic way in which practical modern yoga interprets and assimilates elements of the Indian core tradition, with functionalism almost always prevailing over ritualism. The more generalised entry into New Age vernacular of the word mantra since the 1970s to signify 'a byword, slogan, or catchphrase' (OED 2nd edition 1989) was no doubt facilitated by early purveyors of yoga to the West, such as Swami Sivananda, who perhaps did more than anyone else in the first half of the twentieth century to popularise yoga through an avalanche of cheap publications and pamphlets. His Practice of Yoga of 1929 shows the immense influence that Couéism and cults of positive thinking like New Thought were exerting on popular, early modern elaborations of yoga. Writing of the practice of 'Auto-Suggestion', Sivananda declares,

This practice is an offshoot of Vedantic Sadhana, Aha Brahm Asmi or 'Sivoham'. This is nothing new to India. It is a new colouring, a new garb. The mantra is ' $I$ am becoming better, and better, every day, and every way.' Constantly repeat this mentally [...] Never give room for dark negative thoughts [...] Assert strongly. Affirm. You will feel tremendous strength and power. ${ }^{44}$

Apart from the by now familiar refrain that auto-suggestion is just an adaptation of ancient Indian knowledge, this passage exemplifies the reign of Couéism in early transnational yoga, and demonstrates the willingness of certain prophets of the new movement, like Sivananda, to adapt yoga and Vedänta to the cult of positive thinking. ${ }^{45}$ What is at stake here is not mere 'colouring', but the fundamental orientation and definition of yoga itself. Sivananda is not alone in this. Ramayandas counsels against using Sanskrit words for mantra, reasoning that 'it is the meaning of the word that really counts'. In their stead, one should repeat the predictable formula 'I am getting better every day'

${ }^{43}$ Eliade 1969, p. 212.

44 Sivananda 1929, pp. 245-6.

${ }^{45}$ Sivananda's penchant for affirmation has been enshrined in his disciple Vishnudevananda's five 'Fundamental Points of Yoga' as 'Meditation and Positive Thinking'. Vishnudevananda established the transnational 'Sivananda Yoga Vedanta' movement, one of the most widely influential of all transnational yogas in the twentieth century (cf. Strauss 2005). 
which, he assures the reader, acts much in the same way as the Sanskrit mantra. ${ }^{46}$ This is evidently at odds with the 'bizarre and unintelligible phonemes' whose 'meaning did not belong to rational language' that Eliade identifies as the essential components of mantra practice. ${ }^{47}$

In its more extreme expressions, then, mantra functions as a cosmic wishlist for the subconscious mind. The ritual framework that gives mantra its full significance in the Hindu tradition is lacking in many modern forms of yoga, where virtually anything goes-the sole criterion, that it feels right. The personalised religion that modern yoga offers allows the individual to invest 'yoga practices' with a personal significance that would probably not have been available in the same way in a heavily ritualised, pre-modern Hindu universe. When the glossy American monthly Yoga Journal recommends using short, affirmative statements 'as a mantra during pranayama or meditation practice', or encourages the reader to 'Resolve to Evolve' using 'a New Year's resolution with a yogic twist', it is heir to New Thought doctrines which became enshrined in popular yoga in the early part of the twentieth century. ${ }^{48}$ These doctrines seem to have had little to do with yoga before that time, and represent a radical and eclectic revisioning of the deeper purpose of the tradition in thisworldly, materialistic terms.

\section{The New Body}

It would be a mistake to overlook the primacy of physically embodied existence in the scheme of New Thought-a movement whose primary concern, after all, is with the holistic health of the individual. Nonetheless, histories of mind cure have tended to focus far more on the cerebral and spiritual aspects of the movement while leaving the body largely to one side. 'Even the more sophisticated accounts of turn-of-the-century New Thought', Marie Griffith rightly asserts, 'have failed to perceive one of the movement's salient features: the absolute centrality of the body for pushing the individual along the path of advancement'. ${ }^{49}$ The body was seen in essence to be a malleable and perfectible instrument which, through rigorous mental control, could be brought into the thrall of the mind and spirit. The faultless health which resulted from this would in turn make the goal of moral and spiritual perfection more attain-

\footnotetext{
46 Ramayandas 1926 , p. 51.

47 Eliade 1969, p. 213.

48 Guthrie 2005a and b respectively.

49 Griffith 2001, p. 125.
} 
able, by harmonising the physical being with the cosmic mind. In Ralph Waldo Trine's words, 'Mind Builds Body' as surely as 'Body Helps Mind'. ${ }^{0}$ Griffith notes,

No longer was the aim of disciplining the body to appease a mysterious God or to make oneself into a purer vessel for receiving the divine will. Rather, the point was to align oneself with the rational cosmic force commonly referred to as Mind, All-Supply, or Universal Spirit and thereby attract to oneself the abundance that had once seemed unattainable. ${ }^{51}$

To this end, the New Thoughters developed vigorous regimes of fasting, diet, physical training, and nature cure. These functioned not as aids to fitness, but as tools to prise open the sluicegates of godliness that resided within the corporeal frame. The health that resulted from these regimes was not envisaged as a merely physiological response to sustained bodily exertion, but as a gauge of spiritual progress. Because, as Trine puts it, '[a]ll body building, the same as all body repairing-healing-is accomplished through the operation of the Lifeforces within'. ${ }^{52}$

\section{Payot, Haddock, Yogananda}

An influential precursor of the New Thought theory and practice of the body was Jules Payot's immensely popular The Education of the Will, published in 1893, the same year that Vivekananda arrived in America to begin his modern yoga mission. Within 13 years, Payot's book had been 'translated into most European tongues' and gone through 27 editions. ${ }^{53}$ For Payot, as for the New Thoughters, the body held the secret of spiritual advancement, and it was through developing the 'healthy animal' that the god in man would be revealed. $^{54}$ The 'physiological conditions of self-mastery' were to be attained through a regime of muscular exercise and 'Respiratory gymnastics' which would function as 'a primary school for the will'. ${ }^{55}$ Payot's ideas, and methods, were taken up by the New Thought movement, and developed in the writings of such figures as Frank Channing Haddock, whose 'Power Book Library' series represents a significant event in twentieth-century New Thought history. Haddock draws heavily on Payot's work in his Power of the Will of 1909.

so Trine 1913, p. 190.

51 Griffith 2001, p. 124

52 Trine 1913, p. 195.

53 Payot 1909, p. ix.

54 Payot 1909, p. 247.

55 Payot 1909, pp. 259, 265. 
The physical exercises he describes therein are based, as for Payot, on the exertion of the will—not for physical gains, but for the training of the will itself, and for the moral and spiritual benefit to be derived from this training. During the exercises, one repeatedly affirms 'I am receiving helpful forces! [...] Streams of power for body and mind are flowing in!'. However, one should send such affirmations into the body itself, rather than outwards towards the cosmos, and 'throw' the thought 'into the limbs and muscles'. ${ }^{56}$ The exercises in Haddock's book represent a kind of embodied Couéism, in so far as affirmations are combined with physical exercise to create the corporeal conditions for cosmic influx.

This association of mind-cure techniques and 'physical' yoga is a pervasive trend throughout the early history of yoga in the West. For example, the techniques of mental control and physical perfection taught by Paramahansa Yogananda (1893-1952) in the first years of his ministry in America are often a perfect match for those of contemporary, yogic-minded New Thoughters. Yogananda, who would later author the bible of mystical India, Autobiography of a Yogi (1946), and inspire several generations of western spiritual seekers, was the most successful of a small but influential contingent of New Thoughtinspired Indian yogins operating on the West coast of America in the mid$1920 s .{ }^{57}$ During his first years in America, Yogananda taught a version of yogic 'muscle control' heavily influenced by New Thought and Payotian bodybuilding. This method of 'muscle recharging through will power', he claims, had been 'discovered' by him in 1916 and tested on students at his school in Ranchi. $^{58}$ Thereafter, these students performed prodigious 'feats of strength and endurance'. ${ }^{59}$

Yogananda's early publications in America promote this auto-suggestive, quick-fix method of apparatus free gymnastics, which is said to yield 'the highest possible degree of physical, mental and spiritual well-being at the minimum expenditure of time and effort'. ${ }^{60}$ The 'Yogoda... system of body perfection', trumpets another advertisement, can be practised anywhere, 'puts on or removes fat', and 'teaches the spiritualization of the body', ${ }^{1}$ in an efficient merger of the cosmic and the cosmetic. His Yogoda system, defined as 'Body Perfection by Will', shows an unambiguous debt to the vogue of New Thought,

\footnotetext{
56 Haddock 1919 [1909], p. 162.

57 See Singleton 2007.

58 Yogananda 1946, p. 374.

59 Yogananda 1946, p. 248.

60 Yogananda 1925b, pp. 10-11.

61 In Yogananda 1925a.
} 
and in particular to the work of Payot and Haddock. ${ }^{62}$ His system, he declares, was 'perfected ages ago by East Indian saints and rishis', but is at the same time 'an epoch-making discovery in the science of physical and inner culture', an ambiguity characteristic of modern yoga's dual rhetoric of innovation and fidelity to tradition. ${ }^{63}$

The result of his muscle control practices is the 'crystalizing into tissue adjustments and a harmonious integration of the psycho-physical factors of life' ${ }^{64}$ In other words, focusing the will on the performance of the exercises aligns the individual system at a fundamentally material level, and as a result of this, not only spiritual perfection, but also affluence ensue. The Yogoda system teaches one 'how to focus all mental power on one object at a time, on business or cosmic consciousness'. ${ }^{65}$ Here, as in New Thought, economic gain is the natural bedfellow of spiritual profit, both flowing from the cellular readjustment that comes through wilful control of the muscular system. Yogananda's principal crowd-puller during these early years, indeed, was his displays of muscle mastery through will-power, and it is little wonder that the Boston Post of 1923 calls him 'the Coué of gymnastics'. ${ }^{60}$

We might also note here, with regard to the role of auto-suggestion in 'physical' yoga, the remarkable case of an unnamed friend of William James, who undertook a self-directed hatha sadhana in the early years of the twentieth century. After describing his friend's regimen, James concludes that the essence of his project was 'the truth at the bottom of all mind-cures', further identifying hatha yoga itself as a programme of 'suggestive therapeutics' and the would-be yogin's 'whole performance' as 'an experiment in self-suggestion'. ${ }^{67}$ New Thought provided a framework within which the strange, distrusted practices of the hatha yogin (so often the focus of sensationalised ethnographic celebration or censure) could be domesticated for the American and European public. Indeed, Swami Vivekananda's own minimalist advice on health in his foundational modern yoga text of 1896, Raja Yoga, shows the same kind of syncretism with regard to yogas of the body, as well as a surprising willingness to incorporate extraneous American elements into his yoga system. ${ }^{68} \mathrm{De}$

${ }^{62}$ Yogananda $1925 \mathrm{~b}, \mathrm{p}$. 7. It is significant that these early teachings are today largely absent from the literature of the Self Realization Fellowship, Yogananda's official mouthpiece in America.

${ }_{63}$ Yogananda 1925b, p. 11.

${ }_{64}$ Yogananda 1925b, p. 19.

${ }^{65}$ Yogananda 1925b, p. 37.

${ }^{66}$ Cited in Yogananda 1925b, p. 44.

${ }^{67}$ James 1907, p. 328.

${ }^{68}$ De Michelis 2004 argues that this text forms a blueprint for popular expressions of yoga up to this day. 
Michelis has noted that Vivekananda's reinterpretation of Patañjali in Raja Yoga is ' $[s]$ trongly influenced by the New Thought styles of metaphysical teachings' ${ }^{69}$ For example, after whole-heartedly rejecting the practices of hatha yoga, he urges the reader to "[a]lways use a mental effort, what is usually called "Christian Science", to keep the body strong. ${ }^{70}$ From the outset, then, modern yoga in the wake of Vivekananda relied on popular cults of positive thinking to lend coherency and familiarity to practices (such as hatha yoga) which in and of themselves were deemed outlandish and unpalatable.

\section{Yogi Ramacharaka}

An account of the infiltration of New Thought theory and practice into modern yoga would be incomplete without mention of the popular series of books by Yogi Ramacharaka. These publications represent, in Jackson's words, 'the outer limits of New Thought's deep infatuation with India. ${ }^{71}$ Ramacharaka was in all likelihood the pen-name of prolific Chicago lawyer and New Thought 'guru' William Walker Atkinson (1862-1932), who authored a steady avalanche of esoteric yoga manuals and New Thought self-help books between 1903 and about 1917. As Catherine Albanese has very recently noted, Atkinson's work expresses 'New Thought in its brashest, least Christianized and God-dependent version'. ${ }^{72}$ In his autobiography, Sir Paul Dukes, an influential early personage in the introduction of yoga to Britain, recounts his own search for this mysterious figure. Arriving at Atkinson's Yogi Publication Society in Chicago, he requests a meeting with 'the Indian gentleman who wrote these books'. The hard-nosed, gum-chewing secretary explains scornfully that the Indian name is a front-for 'who'd read 'em if they was written by a Mr Atkins?', ${ }^{73}$ and concludes that ' $[\mathrm{h}] \mathrm{e}$ writes it all up from other people's books because it pays'. When Dukes asks if he can meet him, he is told that the man is 'away in Florida doing deals in real estate' ${ }^{74}$ Whatever the truth of this anecdote (clearly written for comic effect), and of Ramacharaka's actual

69 De Michelis 2004, p. 168.

70 Vivekananda 2001 [1896], p. 139. French argues that for many Americans, movements like Theosophy, Christian Science, New England Transcendentalism and New Thought were 'way stations between participations in the institutional Church and an identification with [Vivekananda's] Vedanta' (French 1974, p. 299).

71 Jackson 1975, p. 537.

72 Albanese 2007, p. 358.

${ }^{73}$ Dukes, writing several decades after the incident, has inaccurately remembered Atkinson's name.

${ }^{74}$ Dukes 1950, p. 121. 
identity, there is no doubt that the tremendously popular series of practicallyoriented manuals and courses that he authored had a lasting effect on the propagation of yoga in the West. His books are still read by practitioners today, as the recent republication of his complete works attests.

As a final example of the role of the 'suggestible body' in modern yoga, let us briefly consider Ramacharaka's Hatha Yoga, or the Yogi Philosophy of Physical Well-Being of 1904 . As we have seen, the New Thought body is a malleable and perfectible instrument in the hands of the spirit. The organism is made tractable to the will through a combination of physical discipline and suggestion, such that the corporeal, cellular structure tessellates with the cosmic matrix in a relationship of perfect harmony. When this chord is struck, the anomaly of disease is eradicated and a natural state of health ensues. Once Ramacharaka (here as elsewhere echoing Vivekananda's own sentiments) has made it clear that the fundamental practices of hatha yoga such as kriya and asana are the circus tricks of fakirs, he adopts an essentially romantic nature cure approach to bodily well-being, recommending the standard range of sunbathing, fresh air, water bathing and gentle callisthenic exercise. As for Yogananda, physical perfectionism figures strongly in this version of hatha yoga, and the reader is urged to 'form an idea of the Perfect Body', so that the intelligent force of Life can course through the individual frame and make the body over: for this creative universal force is not impersonal energy, but a beneficent entity 'which is anxious to flow through us. ${ }^{75}$ As with Payot, Haddock and Yogananda, success in Ramacharaka's physical system relies on the ability of the student to '[throw] the mind out' into the body. Once this " $k$ nack" of sending the mind to the desired part' is acquired, then positive messages can be injected into the physical frame in order to eradicate disease. ${ }^{76}$ The author admits that "[ $t$ ] he auto-suggestions and affirmations of the Western world work in this way'. ${ }^{77}$ This method is used in combination with generalised positive suggestions, such as 'BRIGHT, CHEERFUL AND HAPPY'-Couéisms which are, predictably, identified as 'mantrams'.$^{78}$ Modern yogic procedures such as these began with early authors such as Ramacharaka and are still pervasive in many of the heterodox styles of neo-hatha yoga today. ${ }^{79}$

\footnotetext{
${ }^{75}$ Ramacharaka 1904, pp. 242-3.

${ }^{76}$ Ramacharaka 1904, p. 192.

77 Ramacharaka 1904, p. 144.

${ }^{78}$ Ramacharaka 1904, p. 237.

${ }^{79}$ Once again, I refer the reader to Albanese 2007 (pp. 358-61) for a fuller analysis of Ramacharaka's work.
} 


\section{Conclusion}

Geoffrey Samuel recently observed (in this journal) that in Tibetan medicine's passage to a modern, western paradigm, practitioners tend to foreground those elements which are compatible with the prevalent worldview, but 'marginalise or exclude elements that disrupt that compatibility' ${ }^{80} \mathrm{~A}$ similar dynamic is at work throughout the history of New Thought's dalliance with modern yoga. Elements of the Indian tradition are selectively or partially reworked to fit the prevailing doctrine, and those aspects which clash are either rejected or rewritten. A majority of exported or homegrown varieties of modern yoga are hybrids of the Indian systems to which they claim fealty. Adapted to suit local tastes and expectations, they may, as Beckerlegge puts it, "legitimately said to represent a degree of strategic, "glocal" tweaking of received Hindu tradition'. ${ }^{81}$ Such 'tweaking' occurs not only on the side of India-infatuated western esotericists, but also within the élite ranks of modern Indian yoga teachers (from at least Vivekananda onwards), who recognise the utility of these 'new' concepts in the national and international dissemination of their systems. As the Rajah of Aundh makes clear in the epigraph to this article, positive-thinking luminaries like Coué, Haddock and James were welcomed into the yoga revival as antidotes to the general amnesia which had swept the memory of ancient techniques out of the modern Indian psyche. This tacit mutual accord regarding the compatibility of the two traditions was one of the most significant events in the founding of modern yoga, and continues to inform the tenor and practical applications of popular yoga today.

\section{References}

Ahlstrom, Sydney E. 1972, A Religious History of the American People, New Haven: Yale University Press.

Albanese, Catherine L. 1992, America, Religions and Religion, Belmont, Calif.: Wadsworth.

2007, A Republic of Mind and Spirit : A Cultural History of American Metaphysical Religion, New Haven, Conn. ; London: Yale University Press.

Allen, Abel Leighton 1914, The Message of New Thought, London: Harrap.

Alter, Joseph S. 2005, 'Modern Medical Yoga: Struggling with a History of Magic, Alchemy and

Sex', Asian Medicine, Tradition and Modernity, 1(1): 119-46.

${ }^{80}$ Samuel 2006, p. 72.

${ }^{81}$ Beckerlegge 2004, p. 309. Roland Robertson's (1992) term 'glocalization' refers to 'the provision within global marketing for the marketing of difference according to local taste' (ibid.). 
Anderson, Benedict 1993, 'The New Thought Movement: A Link between East and West'. Speech delivered at the parliament of the world's religions, Chicago, 3 September, 1993. http://websyte.com/alan/parl.htm, last accessed May 2004.

Atkinson, William Walker 1911, The Message of the New Thought, London: L. N. Fowler.

Atkinson, William Walker and Edward E. Beals 1922, Personal Power or Your Master Self, London: L. N. Fowler.

Beckerlegge, Gwilym 2004, 'The Early Spread of Vedanta Societies: An Example of "Imported Localism"', Numen, 51(3): 296-320.

Bharati, A. 1976, The Light at the Center, Context and Pretext of Modern Mysticism, Santa Barbara: Ross-Erikson.

Christy, Arthur 1932, The Orient in American Transcendentalism : A Study of Emerson, Thoreau, and Alcott, New York: Columbia University Press.

Coster, Geralidine 1934. Yoga and Western Psychology: A Comparison, London: Oxford University Press.

De Michelis, Elizabeth 2004, A History of Modern Yoga, Patañjali and Western Esotericism, London and New York: Continuum.

Dresser, Horatio W. 1917, Handbook of the New Thought, New York and London: G. P. Putnam's Sons.

- n.d., A History of the New Thought Movement, London: Harrap.

Dukes, Paul 1950, The Unending Quest: Autobiographical Sketches, London: Cassell.

Eliade, Mircea 1969, Yoga, Immortality and Freedom, London: Routledge and Kegan Paul.

Ferretti, Andrea 2005, 'Just Bead It', Yoga Journal, 186: 20.

French, Harold W. 1974, The Swan's Wide Waters : Ramakrishna and Western Culture, Port Washington, NY: Kennikat Press.

Fuller, Robert C. 2001, Spiritual But Not Religious, Understanding Unchurched America, Oxford; New York: Oxford University Press.

Griffith, R. Marie 2001, 'Body Salvation: New Thought, Father Divine, and the Feast of Material Pleasures', Religion and American Culture, 11(2): 119-53.

Grinshpon, Yohanan 2002, Silence Unheard: Deathly Otherness in Pätañjala-yoga, Albany, NY: State University of New York Press.

Guthrie, Catherine 2005a, 'Resolve to Evolve', Yoga Journal, 186: 20-1.

- 2005b, 'Sankalpa Setting', Yoga Journal, 186: 21.

Haddock, Frank Channing 1919 [1909], The Power of Will, Meriden, Conn. and London: Pelton and L. N. Fowler.

Hara, O. Hashnu 1906, Practical Yoga, with a chapter devoted to Persian Magic, London: L. N. Fowler and Co.

Hatcher, Brian A. 1999, Eclecticism and Modern Hindu Discourse, New York; Oxford: Oxford University Press.

Jackson, Carl T. 1975, 'The New Thought Movement and the Nineteenth-Century Discovery of Oriental Philosophy', Journal of Popular Culture, 9: 523-48.

- 1981, The Oriental Religions and American Thought : Nineteenth-Century Explorations, Westport, Conn.; London: Greenwood.

James, William. 1907, 'The Energies of Man', Science, 25: 321-32.

McLaurin, Hamish 1933, Eastern Philosophy for Western Minds: An Approach to the Principles and Modern Practice of Yoga, Boston, Mass: The Stratford Co.

Melton, J. Gordon 1990, New Age Encyclopedia, Detroit and London: Gale Research Institute.

Meyer, Donald 1965, The Positive Thinkers, New York: Doubleday and Co.

Nivedita, S. 1967, The Complete Works of Sister Nivedita, Calcutta: Ramakrishna Sarada Mission.

Parker, Gail Thain 1973, The History of Mind Cure in New England, Hanover, NH: University Press of New England. 
Patra, Baroda Prasad 1924, The Mysteries of Nature, Calcutta: S. C. Kavirata.

Payot, Jules 1909 [1893], The Education of the Will, The Theory and Practise of Self-Culture, New York and London: Funk and Wagnalls.

Pinch, V. 2003, 'Bhakti and the British Empire', Past and Present, 179(1): 159-96.

Pratinidhi, Shrimant Balasahib O. 1938, The Ten-Point Way to Health. Surya namaskars, London: J. M. Dent and Sons.

Ramacharaka, Yogi 1903, The Hindu-Yogi Science of Breath : A Complete Manual of the Oriental Breathing Philosophy of Physical, Mental, Psychic and Spiritual Development, Chicago, Ill.: Yogi Publication Society.

— 1904, Hatha Yoga or the Yogi Philosophy of Physical Well-being, Chicago: Yogi Publication Society.

— 1908, The Inner Teachings of the Philosophies and Religions of India, Chicago: Yogi Publication Society.

Ramayandas, Sensanath Devendra 1926, First Steps in Yoga, London.

Rele, Vasant Gangarama 1927, The Mysterious Kundalini: The Physical Basis of the Kundalini (hatha) Yoga according to our Present Knowledge of Western Anatomy and Physiology, Bombay: D. B. Taraporevala.

Robertson, Roland 1992, Globalization : Social Theory and Global Culture, London: Sage.

Samuel, Geoffrey 2006, 'Tibetan Medicine and Biomedicine: Epistemological Conflicts, Practical Solutions', Asian Medicine, Tradition and Modernity, 2(1): 72-86.

Sarbacker, Stuart R. 2005, Samadhi : Numinous and Cessative in Indo-Tibetan Yoga, Albany: State University of New York Press.

Singleton, Mark 2005, 'Salvation Through Relaxation: Proprioceptive Therapy in Relation to Yoga', Journal of Contemporary Religion, 20: 289-304.

- 2007, 'The Body at the Centre: Contexts of Postural Yoga in the Modern Age', unpublished PhD Thesis, Faculty of Divinity, Cambridge, University of Cambridge: p. 228.

Sivananda, Swami 1929, Practice of Yoga, etc., Madras: Ganesh and Co.

_ 1935, Yoga asanas, Madras: P. K. Vinayagam.

Stocker, R. Dimsdale 1906, Yoga Methods. How to prosper in mind, body, and estate, London and New York.

— 1913, The Time Spirit: A Survey of Contemporary Spiritual Tendencies, London: Erskine Macdonald.

Strauss, Sarah 2005, Positioning Yoga : Balancing Acts across Cultures, Oxford: Berg.

Trine, Ralph Waldo 1913, The New Alinement of Life, Concerning the Mental Laws of a Greater Personal and Public Power, London: G. Bell and Sons.

Versluis, Arthur 1993, American Transcendentalism and Asian Religion, New York and Oxford: Oxford University Press.

Vishnudevananda, Swami 1960, The Complete Book of Yoga, London: Souvenir Press.

Vivekananda, Swami 2001 [1896], Raja Yoga, or Conquering the Internal Nature, Calcutta: Advaita Ashrama.

2001 [1893], Chicago Addresses, Calcutta: Advaita Ashrama.

Wase, Charles 1921, The Inner Teaching and Yoga, London: W. Rider.

Yogananda, Paramahamsa 1925a, Psychological Chart, Los Angeles: Yogoda and Sat-Sanga Headquarters.

_ 1925b, General Principles and Merits of Yogoda or Tissue-Will System of Body and Mind Perfection, Originated and taught by Swami Yogananda, Los Angeles: Sat-Sanga and Yogoda Headquarters.

— 1946, Autobiography of a Yogi, New York: The Philosophical Library. 